\title{
膜面の圧カ及び重カによる変形挙動*1 \\ Deflection of a Membrane Strip Subjected to Pressure and Gravity Forces
}

\author{
加 藤 純 郎*2 $・$ 名 取 通 弘*3 \\ Sumio KATO and Michihiro NATORI
}

\author{
Key Words : Structural Analysis, Membrane Deflection, Pressure, Gravity Force, \\ Surface Error, Inflatable Reflector
}

\begin{abstract}
The reflecting surface of an inflatable reflector for space use consists of one or several inflatable elements (membrane elements), which are pressurized to generate an accurate reflecting surface. The surface of an inflatable element deforms as the pressure is applied. If the element is pressurized on the ground, gravity force also changes the deflection of the element. This means that the internal pressure and the gravity force influence the surface error of the element. This paper presents an analysis of the deflection and the surface accuracy of an inflatable element subjected to pressure and gravity loadings based on a flexible membrane strip model, the initial configuration of which is straight or a circle arc, with both ends immovably supported. The gravity is assumed to act in any direction in the plane which includes the membrane strip. The perturbation method is used to solve the membrane deflection due to the gravity force, assuming the ratio of gravity to pressure and the center height of the membrane to be small. The analytical expressions for the deflection and the surface error of the membrane strip subjected to pressure and gravity are obtained. It is found that the effect of gravity on the surface error increases as the ratio of gravity to pressure and the center height of the strip increases, and as the rigidity (Young Modulus) of the membrane decreases. It is also found that if the membrane strip is not so rigid (Young Modulus is not so high), the effect of gravity on the deflection is smallest with the membrane vertically placed. On the other hand if the membrane strip is rigid enough, the effect of gravity is smallest with the membrane horizontally placed.
\end{abstract}

\footnotetext{
1 平成 4 年 2 月 14 日须稿受理

-2 川崎重工業(株)岐阜技術研究所

*3 宇宙科学研究所
}

\section{主 な 記 号}

$t_{\mathrm{h}}:$ 膜厚

$a: \mathrm{AB}$ 間の距離の $1 / 2$

$E:$ ヤング率

$P:$ 圧力

$\mathrm{A}, \mathrm{B}$ : 膜の端部点

$x, y: \mathrm{A}$ 点を原点, 直線 $\mathrm{AB}$ を $x$ 軸, $\mathrm{AB} に$ 垂直な軸を $y$ 軸としたときの膜の $x, y$ 座標

$X, Y: x, y$ の無次元量 $(X=x / a, Y=y / a)$

$q:$ 膜の単位面積に働く重力

$\alpha: q / P$

$v, V: x$ 方向膜力 (単位幅当りに加わる内力)及 びその無次元量 $(V=v /(P a))$

$f, F: y$ 方向膜力及びその無次元量 $(F=$ $f /(P a))$

$t, T:$ 膜力 $\left(t=\left(v^{2}+f^{2}\right)^{1 / 2}\right)$ 及びその無次元量 $(T=t /(P a))$

$s, S: \mathrm{A}$ 点から測った膜の長さ及びその無次 元量 $(S=s / a)$

$\theta$ : 直線 $\mathrm{AB}$ と重力方向のなす角(第 1 図参 照)

$l, L:$ 膜の全長及びその無次元量 $(L=l / a)$

$\sigma:$ 膜に生ずる応力

$\varepsilon:$ 膜に生じる歪み

$r, R$ :膜の半径及びその無次元量 $(R=r / a)$

$h:$ 膜の中心高さ

$\beta: a / r_{0}$

$k: \beta_{\mathrm{u}} / \beta$

$d:$ 膜の鏡面誤差 ( (33) 式)

$e:$ 膜の重力による変形誤差 ((75) 式)

$\delta:$ 変形誤差の無次元量 $(\delta=e / a)$ 
$\delta_{\mathrm{B}}, \delta_{\mathrm{b}} ： \alpha^{1}$ 及び， $\alpha^{2}$ までの項を考慮したときの 変形誤差 ((77)，(78)式)

$C:(80)$ 式

$k_{\mathrm{cr}}: C=0$ とする $k$ の值

$0\left(\beta^{i}\right): \beta^{i}$ の係数の関係式

$\Delta Y, \Delta Y_{\mathrm{a}} \Delta Y_{\mathrm{b}}:(73) ，(74)$ 式

添 字

( ) $)_{\mathrm{u}}$ : 圧力を加える前の値

( $)_{i}: \alpha^{i}$ の係数

( $)_{i, j}: \alpha^{i} \beta^{j}$ の係数

( ) $)_{0}$ : 圧力を加えたときの值

( ) $)_{\mathrm{A}}: \mathrm{A}$ 点での值

1.まえがき

宇宙アンテナや太陽集光器のような放物面状の反射 面を持つ宇宙りフレタクは、これまでに種々の構造方 式が提案されている．インフレータブルリフレクタ構 造 $^{1 \sim 3)}$ はその一つであり，膜面を収納して打ち上げ， 軌道上で展開/加圧して形状を定め，太陽熱等により 膜材を硬化させて反射面として利用する．本構造は軽 量で収納効率が良好であり，また加圧により膜の反射 面の主曲率が同時に正となるため高精度の面が得られ るという特徵を持つ。

膜面を加圧すると膜材の弾性のために表面形状が変 化して鏡面誤差に影響を及ぽす。さらに膜面を地上て 加圧すると重力の影響が加わり，形状及び鏡面誤差が 変化する。

本論文では，まず膜面が加圧された場合の変形形状 を，一次元的な膜面モデルの釣り合い関係式に基ゔ き，解析的に求める．膜の初期形状は直線状又は円弧 状とし，曲げ剛性を持たず，膜の両端は支持され移動 しないものとする．さらに重力が加わった場合につ き，同じ膜面モデルを使用して，重力と圧力の比が小 さいものとして，膜の加圧状態からの重力による変形 量を，摄動法を用いて調べる. 重力の方向は膜を含む 面内で任意の方向に加わるものとし，膜の中心高さは 両端距離に比べ小さく，また歪みも小さいとする。こ れらにより, 圧力/重力による膜面の変形挙動, 及び 形状精度への影響を調べる。

\section{2. 基礎方程式}

第 1 図に示すように，一定膜厚 $t_{\mathrm{h}}$ ，ヤング率 $E$ の 曲げ剛性のない一様な膜片に圧力及び重力が加わるも のとする. 膜片の初期形状は直線又は円弧状で，中心 高さと両端距離 $2 a$ の比は小さく, 両端 $\mathrm{AB}$ は移動し ないとする。膜材は線型弾性膜で初期張力はゼロと し，歪みは小さく膜厚及び単位面積に加わる重力は加

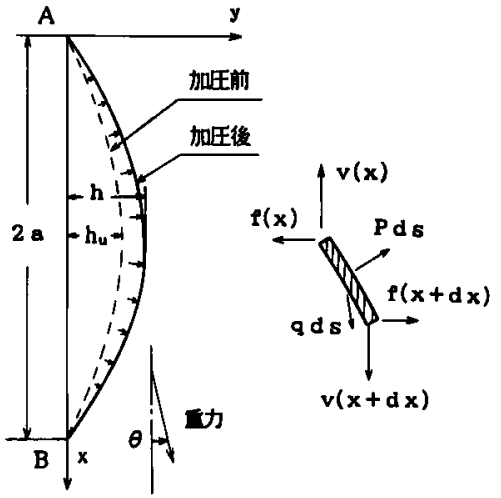

第 1 図 膜面モデル

圧前後で不変とする．以上を仮定すると，膜の微小要 素の釣り合い等より容易に下式が得られる(初期形状 が直線状の膜が加圧された場合の釣り合い式は，文献 4)に示されている).

$$
\begin{aligned}
& \frac{d v}{d x}+q \frac{d s}{d x} \cos \theta-P \frac{d y}{d x}=0 \\
& \frac{d f}{d x}+q \frac{d s}{d x} \sin \theta+P=0 \\
& \frac{d y}{d x}=\frac{f}{v} \\
& x=x\left(x_{\mathrm{u}}\right) \\
& s_{\mathrm{u}}\left(x_{\mathrm{u}}\right)=\int_{0}^{x_{\mathrm{u}}}\left\{1+\left(\frac{d y_{\mathrm{u}}}{d x_{\mathrm{u}}}\right)^{2}\right\}^{1 / 2} d x_{\mathrm{u}} \\
& s(x)=\int_{0}^{x}\left\{1+\left(\frac{d y}{d x}\right)^{2}\right\}^{1 / 2} d x \\
& 1+\varepsilon=d s / d s_{\mathrm{u}} \\
& \varepsilon=t /\left(E t_{\mathrm{h}}\right)=\sigma / E \\
& t=\sqrt{v^{2}+f^{2}}
\end{aligned}
$$

ここで, $v: x$ 方向膜力 (膜の単位幅当りに加わる力), $f: y$ 方向膜力, $P:$ 圧力, $x, y:$ 変形後の膜の座標, $s:$ A 点から測った変形後の膜の長さ， $q$ :膜に働く 単位面積当りの重力， $\theta$ : 重力方向と $x$ 軸のなす角, $\varepsilon$ : 変形による歪み, $\sigma:$ 膜に働く応力, $t:$ 膜力, （）：膜の変形前の值，である.（1-1)〜(1-3)式は それぞれ, 膜の $x$ 方向, $y$ 方向, 及びモーメントの 釣り合い式を，(1-4)式江変形前後の $x$ 座標の関係 を、また(1-5)，(1-6)式は膜の変形前後の長さを示 す。(1-7)式は歪み式，(1-8)式は応力歪み関係式。 (1-9)式は膜力の関係式である.

膜の両端では以下が成り立つ.

$$
y=y_{\mathrm{u}}=0 \quad(x=0,2 a)
$$

$(1-7) ，(1-8)$ 式より $\varepsilon$ を消去すると

$$
d s_{\mathrm{u}}=d s /\left(1+t /\left(E t_{\mathrm{h}}\right)\right)
$$

両辺を膜の全長に渡って積分すると 


$$
\int_{0}^{\iota_{u}} d s_{u}=\int_{0}^{t} \frac{1}{1+t /\left(E t_{n}\right)} d s
$$

ここでい,lはそれそれ膜の変形前後の長さである．

$(1-6)$ 式より $d s=\left\{1+(d y / d x)^{2}\right\}^{1 / 2} d x$ として (4) 式 に代入すると下式を得る。

$$
l_{\mathrm{u}}=\int_{0}^{2 a} \frac{\sqrt{1+(d y / d x)^{2}}}{1+t /\left(E t_{\mathrm{h}}\right)} d x
$$

ここて， $a, P$ を用いて関係諸量を次のように無次元 化する。

$$
\begin{aligned}
& Y=y / a, \quad Y_{u}=y_{u} / a, X=x / a, \quad S=s / a \\
& V=v /(P a), \quad F=f /(P a), \quad T=t /(P a), \quad L=l / a \\
& L_{u}=l_{u} / a, \quad \alpha=q / P
\end{aligned}
$$

これらの無次元量を用いると $(1-1) 〜(1-3) ，(1-6)$ ， (1-8)，(1-9)，(2)，(5)式は以下で表わされる.

$$
\begin{aligned}
& \frac{d V}{d X}+a \frac{d S}{d X} \cos \theta-\frac{d Y}{d X}=0 \\
& \frac{d F}{d X}+1+\alpha \frac{d S}{d X} \sin \theta=0 \\
& V \frac{d Y}{d X}=F \\
& S(X)=\int_{0}^{X}\left[1+\left(\frac{d Y}{d X}\right)^{2}\right]^{1 / 2} d X \\
& \varepsilon=\frac{P a}{E t_{\mathrm{h}}} T=\frac{\sigma}{E} \\
& T=\sqrt{V^{2}+F^{2}} \\
& Y=Y_{\mathrm{u}}=0 \quad(X=0,2) \\
& L_{\mathrm{u}}=\int_{0}^{2} \frac{\sqrt{1+(d Y / d X)^{2}}}{1+T P a /\left(E t_{\mathrm{h}}\right)} d X
\end{aligned}
$$

\section{3. 解析}

3.1 基礎方程式の解 膜面に加わる重力と圧力の 比 $\alpha$ は小さいとして, 各パラメータは以下で表わさ れるものとする。

$$
\begin{aligned}
& Y=\sum_{n=0}^{\infty} Y_{n} \alpha^{n}, S=\sum_{n=0}^{\infty} S_{n} \alpha^{n}, \quad V=\sum_{n=0}^{\infty} V_{n} \alpha^{n} \\
& V_{\mathrm{A}}=\sum_{n=0}^{\infty} V_{\mathrm{A} n} \alpha^{n}, F=\sum_{n=0}^{\infty} F_{n} \alpha^{n}, \quad F_{\mathrm{A}}=\sum_{n=0}^{\infty} F_{\mathrm{A} n} \alpha^{n} \\
& T=\sum_{n=0}^{\infty} T_{n} \alpha^{n}, \sigma=\sum_{n=0}^{\infty} \sigma_{n} \alpha^{n}, \quad \varepsilon=\sum_{n=0}^{\infty} \varepsilon_{n} \alpha^{n}
\end{aligned}
$$

(8)式を(7-1)〜(7-8)式に代入して， $\alpha$ の級数て 表わし $\alpha^{0}$ の係数を比較すると

$$
\begin{aligned}
& \frac{d V_{0}}{d X}-\frac{d Y_{0}}{d X}=0 \\
& \frac{d F_{0}}{d X}+1=0 \\
& V_{0} \frac{d Y_{0}}{d X}=F_{0} \\
& S_{0}=\int_{0}^{x}\left[1+\left(\frac{d Y_{0}}{d X}\right)^{2}\right]^{1 / 2} d X
\end{aligned}
$$

$$
\begin{aligned}
& \varepsilon_{0}=\frac{P a}{E t_{\mathrm{h}}} T_{0}=\frac{\sigma_{0}}{E} \\
& T_{0}=\sqrt{V_{0}^{2}+F_{0}^{2}} \\
& Y_{0}=Y_{\mathrm{u}}=0 \quad(X=0,2) \\
& L_{u}=\int_{0}^{2} \frac{\left(1+\left(d Y_{0} / d X\right)^{2}\right)^{1 / 2}}{1+T_{0} P a /\left(E t_{\mathrm{h}}\right)} d X
\end{aligned}
$$

(9-1)〜(9-8)式は重力がなく圧力のみが加わった場 合の関係式を表わす. 同様にして $\boldsymbol{\alpha}^{1}$ の係数を比較す ると

$$
\begin{aligned}
& \frac{d V_{1}}{d X}+\frac{d S_{0}}{d X} \cos \theta-\frac{d Y_{1}}{d X}=0 \\
& \frac{d F_{1}}{d X}+\frac{d S_{0}}{d X} \sin \theta=0 \\
& V_{1} \frac{d Y_{0}}{d X}+V_{0} \frac{d Y_{1}}{d X}=F_{1} \\
& S_{1}=\int_{0}^{x} \frac{d Y_{0} / d X \cdot d Y_{1} / d X}{\sqrt{1+\left(d Y_{0} / d X\right)^{2}} d X} \\
& \varepsilon_{1}=P a T_{1} /\left(E t_{\mathrm{h}}\right)=\sigma_{1} / E \\
& T_{1}=\left(V_{0} V_{1}+F_{0} F_{1}\right)\left(V_{0}^{2}+F_{0}^{2}\right)^{-1 / 2} \\
& Y_{1}=Y_{\mathrm{u}}=0 \quad(X=0,2) \\
& \int_{0}^{2}\left[-\frac{\sqrt{1+\left(d Y_{0} / d X\right)^{2}}}{M^{2}} \frac{P a}{E t_{\mathrm{h}}} T_{1}\right. \\
& \left.\quad+\frac{d Y_{0} / d X \cdot d Y_{1} / d X}{M \sqrt{1+\left(d Y_{0} / d X\right)^{2}}}\right] d X=0
\end{aligned}
$$

但し，

$$
M=1+T_{0} P a /\left(E t_{\mathrm{n}}\right)
$$

$\alpha^{2}$ の係数に対応する関係式は

$$
\begin{aligned}
& \frac{d V_{2}}{d X}+\frac{d S_{1}}{d X} \cos \theta-\frac{d Y_{2}}{d X}=0 \\
& \frac{d F_{2}}{d X}+\frac{d S_{1}}{d X} \sin \theta=0 \\
& V_{0} \frac{d Y_{2}}{d X}+V_{1} \frac{d Y_{1}}{d X}+V_{2} \frac{d Y_{0}}{d X}=F_{2} \\
& S_{2}=\int_{0}^{x}\left[\frac{\left(d Y_{1} / d X\right)^{2}+2 d Y_{0} / d X \cdot d Y_{2} / d X}{2 \sqrt{1+\left(d Y_{0} / d X\right)^{2}}}\right. \\
& \left.\quad-\frac{\left(d Y_{0} / d X\right)^{2}\left(d Y_{1} / d X\right)^{2}}{2\left[1+\left(d Y_{0} / d X\right)^{2}\right]^{3 / 2}}\right] d X \\
& \varepsilon_{2}=\frac{P a}{E t_{\mathrm{h}}} T_{2}=\frac{\sigma_{2}}{E} \\
& T_{2}=\frac{2 V_{0} V_{2}+2 F_{0} F_{2}+V_{1}^{2}+F_{1}^{2}}{2 \sqrt{V_{0}^{2}+F_{0}^{2}}} \\
& \quad-\frac{\left(V_{0} V_{1}+F_{0} F_{1}\right)^{2}}{2\left(V_{0}^{2}+F_{0}^{2}\right)^{3 / 2}} \\
& Y_{2}=Y_{4}=0\left(X^{2}=0,2\right) \\
& \int_{0}^{2}\left[-\frac{1}{2 M}\left(\frac{d Y_{0}}{d X}\right)^{2}\left(\frac{d Y_{1}}{d X}\right)^{2} N^{-3 / 2}\right. \\
& \quad+\left\{-\frac{1}{M^{2}} \frac{P a}{E t_{\mathrm{h}}} T_{1} \frac{d Y_{0}}{d X} \frac{d Y_{1}}{d X}+\frac{1}{2 M}\left(\frac{d Y_{1}}{d X}\right)^{2}\right. \\
& \left.\quad+\frac{1}{M} \frac{d Y_{0}}{d X} \frac{d Y_{2}}{d X}\right\}^{-1 / 2}+\left\{-\frac{1}{M^{2}} \frac{P a}{E t_{\mathrm{h}}} T_{2}\right.
\end{aligned}
$$




$$
\left.\left.+\frac{1}{M^{3}}\left(\frac{P a}{E t_{\mathrm{h}}}\right)^{2} T_{1}^{2}\right\} N^{1 / 2}\right] d X=0
$$

但し。

$$
N=1+\left(d Y_{0} / d X\right)^{2}
$$

\section{2 各オーダーの解}

3.2.10次解 本項では(9-1)〜 (9-8)式に基ゔき $Y_{0} 、 V_{0}$ 等を求める。(9-1)，(9-2)式を積分して境界 条件(9-7)式を考虑すると，下式を得る。

$$
\begin{aligned}
& V_{0}=Y_{0}+V_{\mathrm{A} 0} \\
& F_{0}=-X+F_{\mathrm{A} 0}
\end{aligned}
$$

ここで $V_{\mathrm{A} 0}, F_{\mathrm{A} 0}$ は各々 $V_{0}, F_{0}$ のA点での值であ る.

（12），(13)式を(9-3)式に代入して，変数分離によ り積分し(9-6)式および境界条件 (9-7)式を考虑すると

$$
\left(Y_{0}+V_{\mathrm{A} 0}\right)^{2}+\left(X-F_{\mathrm{A} 0}\right)^{2}=V_{\mathrm{A} 0}{ }^{2}+F_{\mathrm{A} 0}{ }^{2}=T_{\mathrm{A} 0}{ }^{2}
$$

$$
F_{\mathrm{A} 0}=1
$$

又は

$$
\begin{aligned}
& \left(y_{0}+v_{\mathrm{A} 0} / P\right)^{2}+(x-a)^{2}=\left(t_{\mathrm{A} 0} / P\right)^{2} \\
& f_{\mathrm{A} 0}=a P
\end{aligned}
$$

但し, $T_{\mathrm{A} 0}, f_{\mathrm{A} 0}, v_{\mathrm{A} 0}, t_{\mathrm{A} 0}$ は各々 $T_{0}, f_{0}, v_{0}, t_{0}$ の $\mathrm{A}$ 点における値である。(14-3)式は $(x, y)$ 座標系で( $a$, $\left.-v_{\mathrm{A} 0} / P\right)$ を中心とし $t_{\mathrm{A} 0} / P$ を半径とする円を表わす すなわち加圧された膜は円弧になることがわかる．膜 の加圧前も円弧又は直線状であるから，下式が成り立 ว.

$$
\begin{aligned}
& a / r_{0}=2 h_{0} a /\left(a^{2}+h_{0}{ }^{2}\right) \\
& a / r_{u}=2 h_{u} a /\left(a^{2}+h_{u}{ }^{2}\right)
\end{aligned}
$$

ここて $r_{\mathrm{u}}, r_{0}$ は加圧前後の半径, $h_{\mathrm{u}}, h_{0}$ は加圧前後 の中心点の高さである.ここで以下の無次元パラメー 夕を定義する。

$$
\begin{aligned}
& \beta=a / r_{0}, \quad \beta_{\mathrm{u}}=a / r_{\mathrm{u}} \\
& R_{0}=r_{0} / a, R_{\mathrm{u}}=r_{\mathrm{u}} / a
\end{aligned}
$$

(15)，(16-1)，(16-2)式ょり $R_{0}, R_{\mathrm{u}}, \beta ， \beta_{\mathrm{u}}$ は 式で表わされる.

$$
\begin{array}{ll}
R_{0}=1 / \beta, R_{\mathrm{u}}=1 / \beta_{\mathrm{u}} & (16-3) \\
\beta=2 h_{0} a /\left(a^{2}+h_{0}{ }^{2}\right), \beta_{\mathrm{u}}=2 h_{\mathrm{u}} a /\left(a^{2}+h_{\mathrm{u}}{ }^{2}\right) & (16-4)
\end{array}
$$

膜の中心高さと両端距離の比が小さいため, $\beta, \beta_{\mathrm{u}}$ は 小さい值となる.

$X=1, Y_{0}=h_{0} / a$ を(14-1)式に代入し(14-2)式を考 慮すると、下式を得る。

$$
V_{\mathrm{A} 0}=\left(a / h_{0}-h_{0} / a\right) / 2
$$

(16-4)式を考虑すると， $V_{\mathrm{A} 0}$ は以下となる

$$
\begin{aligned}
V_{\mathrm{A} 0} & =\sqrt{1-\beta^{2}} / \beta \\
& =1 / \beta-\beta / 2-\beta^{3} / 8+\cdots
\end{aligned}
$$

(14-2)，(17-2)式を(14-1)式に代入して $Y_{0} \geqq 0$ を考 慮すると

$$
\begin{aligned}
Y_{0} & =\left(\sqrt{1-\beta^{2}(X-1)^{2}}-\sqrt{1-\beta^{2}}\right) / \beta \quad(18-1) \\
\beta \text { の級数で表わすと } & \\
Y_{0}=\sum_{n=1,3,5 \cdots \cdots}^{\infty} Y_{0, n} \beta^{n}= & -(\beta / 2)\left\{(X-1)^{2}-1\right\} \\
& \quad-\left(\beta^{3} / 8\right)\left\{(X-1)^{4}-1\right\}+\cdots
\end{aligned}
$$

(12)，(13)式を(9-6)式に代入し，(14-1)式を考虑 すると

$$
T_{0}^{2}=V_{\mathrm{A} 0}{ }^{2}+F_{\mathrm{A} 0}{ }^{2}=T_{\mathrm{A} 0}{ }^{2}
$$

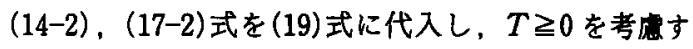
ると

$$
T_{0}=1 / \beta
$$

すなわち膜力 $T_{0}$ は場所によらず一定である．

(17-2)，(18-1)，(14-2)式を(12)，(13)式に代入す ると

$$
\begin{aligned}
V_{0}= & \sqrt{1-\beta^{2}(X-1)^{2}} / \beta \\
=\sum_{n=-1,1,3 . .}^{\infty} V_{0, n} \beta^{n}= & 1 / \beta-(\beta / 2)(X-1)^{2} \\
& -\left(\beta^{3} / 8\right)(X-1)^{4}+\cdots
\end{aligned}
$$

$$
F_{0}=1-X
$$

膜力 $T_{0}$ は一定であるから $(9-8)$ 式を変形すると

$$
L_{\mathrm{u}} \cdot\left(1+P a T_{0} /\left(E t_{\mathrm{h}}\right)\right)=\int_{0}^{2}\left(1+\left(d Y_{0} / d X\right)^{2}\right)^{1 / 2} d X
$$

(23)式の右辺は，変形後の膜の長さ $L_{0}=l_{0} / a$ を表わ

す. (23)式を変形すると

$$
\left(L_{0}-L_{u}\right) / L_{u}=\left(l_{0}-l_{u}\right) / l_{u}=P a T_{0} /\left(E t_{h}\right)
$$

膜の変形前後の形状より, 以下の関係が成り立つ.

$$
\begin{aligned}
& l_{0}=2 r_{0} \sin ^{-1}\left(a / r_{0}\right) \\
& l_{u}=2 r_{u} \sin ^{-1}\left(a / r_{u}\right)
\end{aligned}
$$

(15)，(25），(26)式より $r_{0} ， r_{u}$ を消去して(24)式に 代入し，(16-4)，(20)式を考虑すると

$$
\frac{P a}{E t_{\mathrm{h}}}=\frac{\beta_{\mathrm{u}}}{\sin ^{-1} \beta_{\mathrm{u}}} \sin ^{-1} \beta-\beta
$$

$\beta_{u}$ と $\beta$ は以下の関係が成り立つ.

$$
\beta_{u}=k \beta \quad(0 \leqq k \leqq 1)
$$

（28）式を(27)式に代入して $\beta$ の級数て表わすと

$$
\frac{P a}{E t_{\mathrm{h}}}=\frac{1-k^{2}}{6} \beta^{3}-\frac{17 k^{4}+10 k^{2}-27}{360} \beta^{5}+\cdots
$$

（27）式を(9-5)式に代入し(20)式を考慮すると

$$
\varepsilon_{0}=\frac{\beta_{u}}{\sin ^{-1} \beta_{u}} \frac{\sin ^{-1} \beta}{\beta}-1
$$

(28) 式を(30)式に代入すると $\varepsilon_{0}$ は $\beta$ の級数として以 下で表わされる.

$$
\varepsilon_{0}=\frac{1-k^{2}}{6} \beta^{2}-\frac{17 k^{4}+10 k^{2}-27}{360} \beta^{4}+\cdots
$$

$\sigma_{0}$ は(30)式を(9-5)式に代入して得られる．また $S_{0}$ 
は(18-1)式又は(18-2)式を(9-4)式に代入して得られ。 これを $\beta$ の級数て表わすと下式を得る.

$$
S_{0}=X+(1 / 6)\left\{(X-1)^{3}+1\right\} \beta^{2}+\cdots
$$

ベース放物線 $y_{\mathrm{B}}$ に対する膜の鏡面誤差 $d(\geqq 0)$ を以下 て定義する.

$$
\begin{aligned}
& d^{2}=\frac{1}{2 a} \int_{0}^{2 a}\left(y_{0}-y_{\mathrm{B}}\right)^{2} d x \\
& y_{\mathrm{B}}=\left(h_{\mathrm{B}} / a^{2}\right)\left(-x^{2}+2 a x\right)
\end{aligned}
$$

(33)式の両辺を $a^{2}$ で除して，(18-1)，(34)式を考慮 すると、下式が得られる。

$$
\begin{aligned}
\left(\frac{d}{a}\right)^{2}= & \frac{8}{15}\left(\frac{h_{\mathrm{B}}}{a}\right)^{2}-\left(\frac{h_{\mathrm{B}}}{a}\right)\left[-\frac{\sqrt{1-\beta^{2}}}{3 \beta}-\frac{\sqrt{1-\beta^{2}}}{4 \beta^{3}}\right. \\
& \left.+\frac{\left(1-\beta^{2}\right)^{3 / 2}}{2 \beta^{3}}+\frac{\sin ^{-1} \beta}{\beta^{2}}-\frac{\sin ^{-1} \beta}{4 \beta^{4}}\right] \\
& +\frac{1}{\beta^{2}}-\frac{1}{3}-\frac{\sqrt{1-\beta^{2}}}{\beta^{3}} \sin ^{-1} \beta
\end{aligned}
$$

3.2 .21 次解 本項では(10-1)〜(10-8)式に基ゔ き $Y_{1} ， V_{1}$ 等を求める．(10-1)，(10-2)式を積分し (10-7)式を考虑すると

$$
\begin{aligned}
& V_{1}=Y_{1}-S_{0} \cos \theta+V_{\mathrm{Al}} \\
& F_{1}=-S_{0} \sin \theta+F_{\mathrm{A} 1}
\end{aligned}
$$

(12)，(36)，(37)式を(10-3)式に代入して積分し。 $Y_{0}=Y_{1}=0(X=0)$ を考慮すると

$$
\begin{aligned}
Y_{1}\left(Y_{0}+V_{\mathrm{A} 0}\right)= & \int_{0}^{x} S_{0} \frac{d Y_{0}}{d X} \cos \theta d X \\
& +F_{\mathrm{A} 1} X-V_{\mathrm{A} 1} Y_{0} \\
& -\int_{0}^{x} S_{0} \sin \theta d x
\end{aligned}
$$

$Y_{0}=Y_{1}=0(X=2)$ を上式に代入すると，

$F_{\mathrm{Al}}=-\frac{1}{2} \cos \theta \int_{0}^{2} S_{0} \frac{d Y_{0}}{d X} d X+\frac{1}{2} \int_{0}^{2} S_{0} \sin \theta d X$

(18-2)，(32)式を(39)式に代入すると．

$$
\begin{aligned}
& F_{\mathrm{Al}}=F_{\mathrm{A} 1,0}+F_{\mathrm{Al}, 1} \beta+F_{\mathrm{Al}, 2} \beta^{2}+\cdots \\
& F_{\mathrm{Al}, 0}=\sin \theta, F_{\mathrm{Al}, 1}=(\cos \theta) / 3 \\
& F_{\mathrm{Al}, 2}=(\sin \theta) / 6
\end{aligned}
$$

(32)，(40)式を(37) 式に代入すると，

$F_{1}=F_{1,0}+F_{1,1} \beta+F_{1,2} \beta^{2}+\cdots$

$F_{1,0}=(1-X) \sin \theta, \quad F_{1,1}=(\cos \theta) / 3$

$F_{1,2}=-(1 / 6)(X-1)^{3} \sin \theta$

(17-2)。(18-1)式より

$$
\begin{aligned}
\left(Y_{0}+V_{\mathrm{A} 0}\right)^{-1}= & \beta / \sqrt{1-\beta^{2}(X-1)^{2}} \\
= & \beta+(1 / 2)(X-1)^{2} \beta^{3} \\
& +(3 / 8)(X-1)^{4} \beta^{5}+\cdots
\end{aligned}
$$

$V_{A 1}$ は $\beta$ の級数として以下で表わされるものとする.

$$
V_{\mathrm{Al}}=V_{\mathrm{Al},-1} / \beta+V_{\mathrm{Al}, 0}+V_{\mathrm{Al}, 1} \beta+V_{\mathrm{Al}, 2} \beta^{2}+\cdots
$$

（18-2)，(32)，(40)，(42)，(43)式を(38)式に代入す
ると下式を得る。

$$
\begin{aligned}
Y_{1}= & Y_{1,0}+Y_{1,1} \beta+Y_{1,2} \beta^{2}+\cdots \\
Y_{1,0}= & 0, Y_{1,1}=\left(X-X^{2} / 2\right)\left(\sin \theta-V_{\mathrm{A} 1,-1}\right) \\
Y_{1,2}= & -\frac{\cos \theta}{3} X^{3}+\frac{\cos \theta+V_{\mathrm{Al}, 0}}{2} X^{2} \\
& +\left(\frac{\cos \theta}{3}-V_{\mathrm{A} 1,0}\right) X
\end{aligned}
$$

(32)，(43），(44)式を(36)式に代入すると，

$$
\begin{aligned}
& V_{1}=V_{1,-1} / \beta+V_{1,0}+V_{1,1} \beta+\cdots \\
& V_{1,-1}=V_{\mathrm{Al},-1}, V_{1,0}=V_{\mathrm{A} 1,0}-X \cos \theta
\end{aligned}
$$

(21-1)，(21-2)，(22)，(41)，(45)式を(10-6)式に代 入すると，

$$
\begin{aligned}
& T_{1}=T_{1,-1} / \beta+T_{1,0}+T_{1,1} \beta+\cdots \\
& T_{1,-1}=V_{\mathrm{Al},-1,}, T_{1,0}=V_{\mathrm{Al}, 0}-X \cos \theta
\end{aligned}
$$

(18-2)式を考慮すると下式が成り立つ.

$$
\begin{aligned}
& \sqrt{1+\left(d Y_{0} / d X\right)^{2}}=1+(1 / 2)(X-1)^{2} \beta^{2}+\cdots \\
& \left(1+\left(d Y_{0} / d X\right)^{2}\right)^{-1 / 2}=1-(1 / 2)(X-1)^{2} \beta^{2}+\cdots \\
& \left(1+\left(d Y_{0} / d X\right)^{2}\right)^{-3 / 2}=1-(3 / 2)(X-1)^{2} \beta^{2}+\cdots
\end{aligned}
$$

(20)，(27)式より $M=1+T_{0} P a /\left(E t_{n}\right)$ は $X$ に依存し ない.(10-8)式の積分関係式の両辺に $M^{2}$ を乗じ (18-2)，(20)，(29)，(44)，(46)，(47)式を代入して $\beta$ の巾級数で表わすと $\beta^{2}$ の項が最小項となり $\beta^{2}, \beta^{3}$ の係数の関係式 $0\left(\beta^{2}\right), O\left(\beta^{3}\right)$ は以下となる。

$$
0\left(\beta^{2}\right): \int_{0}^{2}\left[\frac{k^{2}-1}{6} T_{1,-1}-(X-1) \frac{d Y_{1,1}}{d X}\right] d X=0
$$

$$
0\left(\beta^{3}\right): \int_{0}^{2}\left[\frac{k^{2}-1}{6} T_{1,0}-(X-1) \frac{d Y_{1,2}}{d X}\right] d X=0
$$

(44)，(46)式を(48)，(49)式に代すると，

$$
\begin{aligned}
& V_{\mathrm{A} 1,-1}=-2(\sin \theta) /\left(k^{2}-3\right) \\
& V_{\mathrm{A} 1,0}=\cos \theta
\end{aligned}
$$

(50)，(51)式を(44)〜(46)式に代入すると $Y_{1}, V_{1}$, $T_{1}$ は以下で表わされる。

$$
\begin{aligned}
& Y_{1}=Y_{1,1} \beta+Y_{1,2} \beta^{2}+\cdots \\
& Y_{1,1}=\left(X-\frac{X^{2}}{2}\right) \frac{k^{2}-1}{k^{2}-3} \sin \theta \\
& Y_{1,2}=-\frac{\cos \theta}{3} X(X-1)(X-2) \\
& V_{1}=V_{1,-1} / \beta+V_{1,0}+\cdots \\
& V_{1,-1}=-\frac{2}{k^{2}-3} \sin \theta, \quad V_{1,0}=(1-X) \cos \theta
\end{aligned}
$$

$T_{1}=T_{1,-1} / \beta+T_{1,0}+\cdots$

$T_{1,-1}=-\frac{2}{k^{2}-3} \sin \theta, \quad T_{1,0}=(1-X) \cos \theta$ 
（29），(54)式を(10-5)式に代入すると下式を得る.

$$
\begin{aligned}
& \varepsilon_{1}=\varepsilon_{1,2} \beta^{2}+\varepsilon_{1,3} \beta^{3}+\cdots \\
& \varepsilon_{1,2}=\frac{1-k^{2}}{3\left(3-k^{2}\right)}, \quad \varepsilon_{1,3}=\frac{1-k^{2}}{6}(1-X) \cos \theta(55)
\end{aligned}
$$

$\sigma_{1}$ は(55)式を(10-5)式に代入して得られる.

(18-2)，(47)，(52)式を(10-4)式に代入すると

$$
\begin{aligned}
& S_{1}=S_{1,2} \beta^{2}+S_{1,3} \beta^{3}+\cdots \\
& S_{1,2}=\frac{(X-1)^{3}+1}{3} \frac{k^{2}-1}{k^{2}-3} \sin \theta \\
& S_{1,3}=(1 / 12)(\cos \theta) X(X-2)\left(3 X^{2}-6 X+4\right)
\end{aligned}
$$

3.2.32 2次解 本項では(11-1)〜（11-8)式に基づ き $Y_{2}, V_{2}$ 等を求める. (11-1)，(11-2)式を積分し (11-7)式を考慮すると

$$
\begin{aligned}
& V_{2}=Y_{2}-S_{1} \cos \theta+V_{\mathrm{A} 2} \\
& F_{2}=-S_{1} \sin \theta+F_{\mathrm{A} 2}
\end{aligned}
$$

(12)，(36)，(57)，(58)式を(11-3)式に代入して積分

し $Y_{0}=Y_{1}=Y_{2}=0(X=0)$ を考虑すると

$$
\begin{aligned}
Y_{2}\left(Y_{0}+V_{\mathrm{A} 0}\right)= & \int_{0}^{x} S_{1} \frac{d Y_{0}}{d X} \cos \theta d X \\
& +F_{\mathrm{A} 2} X-V_{\mathrm{A} 2} Y_{0} \\
& -\int_{0}^{x} S_{1} \sin \theta d x-V_{\mathrm{A} 1} Y_{1}-Y_{1}^{2} / 2 \\
& +\int_{0}^{x} S_{0} \frac{d Y_{1}}{d X} \cos \theta d X
\end{aligned}
$$

$Y_{0}=Y_{1}=Y_{2}=0(X=2)$ を上式に代入すると，

$F_{\mathrm{A} 2}=-\frac{1}{2} \cos \theta \int_{0}^{2} S_{1} \frac{d Y_{0}}{d X} d X+\frac{1}{2} \int_{0}^{2} S_{1} \sin \theta d X$

$$
-\frac{1}{2} \int_{0}^{2} S_{0} \frac{d Y_{1}}{d X} \cos \theta d X
$$

(18-2)，(32)，(52)，(56)式を(60)式に代入すると，

$$
\begin{aligned}
& F_{\mathrm{A} 2}=F_{\mathrm{A} 2,1} \beta+F_{\mathrm{A} 2,2} \beta^{2}+\cdots \\
& F_{\mathrm{A} 2,1}=\frac{\left(k^{2}-1\right) \sin \theta \cos \theta}{3\left(k^{2}-3\right)} \\
& F_{\mathrm{A} 2,2}=\frac{\left(k^{2}-1\right) \sin ^{2} \theta}{3\left(k^{2}-3\right)}
\end{aligned}
$$

（56），(61)式を(58)式に代入すると，

$$
\begin{aligned}
& F_{2}=F_{2,1} \beta+F_{2,2} \beta^{2}+\cdots \\
& F_{2,1}=\frac{\left(k^{2}-1\right) \sin \theta \cos \theta}{3\left(k^{2}-3\right)} \\
& F_{2,2}=-\frac{\left(k^{2}-1\right)(X-1)^{3} \sin ^{2} \theta}{3\left(k^{2}-3\right)}
\end{aligned}
$$

$V_{\mathrm{A} 2}$ は $\beta$ の級数として以下で表わされるものとする.

$$
V_{\mathrm{A} 2}=V_{\mathrm{A} 2,-1} / \beta+V_{\mathrm{A} 2,0}+V_{\mathrm{A} 2,1} \beta+V_{\mathrm{A} 2,2} \beta^{2}+\cdots
$$

$$
(18-2) ，(32) ，(42) ，(43) ，(52) ，(56) ，(61) ，(63)
$$
式を(59)式に代入すると下式を得る.

$$
\begin{aligned}
& Y_{2}=Y_{2,0}+Y_{2,1} \beta+Y_{2,2} \beta^{2}+\cdots \\
& Y_{2,0}=0
\end{aligned}
$$

$$
\begin{aligned}
Y_{2,1}= & -V_{\mathrm{A} 1,-1} Y_{1,1}-V_{\mathrm{A} 2,-1} Y_{0,1} \\
Y_{2,2}= & \int_{0}^{X} X \frac{d Y_{1,1}}{d X} \cos \theta d X-V_{\mathrm{A} 1,0} Y_{1,1} \\
& -V_{\mathrm{A} 1,-1} Y_{1,2}-V_{\mathrm{A} 2,0} Y_{0,1}+F_{\mathrm{A} 2,1} X
\end{aligned}
$$

(56)，（63），(64)式を(57)式に代入すると，

$$
\begin{aligned}
& V_{2}=V_{2,-1} / \beta+V_{2,0}+V_{2,1} \beta+\cdots \\
& V_{2,-1}=V_{\mathbf{A} 2,-1}, V_{2,0}=V_{\mathbf{A} 2,0}
\end{aligned}
$$

(21-1)，(21-2)，(22)，(41)，(53)，(62)，(65)式を

(11-6)式に代入すると，

$$
T_{2}=T_{2,-1} / \beta+T_{2,0}+T_{2,1} \beta+\cdots
$$$$
T_{2,-1}=V_{\mathrm{A} 2,-1}, T_{2,0}=V_{\mathrm{A} 2,0}
$$

(11-8)式の両辺に $M^{2}$ を乗じ，(18-2)，(20), $(21-2) ，(29) ，(47) ，(52) ，(54) ，(64) ，(66)$ 式を代 入して $\beta$ の級数で表わすと， $\beta^{2}$ の項が最小の項とな り $0\left(\beta^{2}\right), O\left(\beta^{3}\right)$ は以下となる.

$$
\begin{aligned}
0\left(\beta^{2}\right): & -\int_{0}^{2} \frac{1-k^{2}}{6} T_{2,-1} d X \\
& +\int_{0}^{2}\left[\frac{1}{2}\left(\frac{d Y_{1,1}}{d X}\right)^{2}+\frac{d Y_{0,1}}{d X} \frac{d Y_{2,1}}{d X}\right] d X=0 \\
0\left(\beta^{3}\right): & -\int_{0}^{2} \frac{1-k^{2}}{6} T_{2,0} d X+\int_{0}^{2} \frac{d Y_{1,1}}{d X} \frac{d Y_{1,2}}{d X} d X \\
& +\int_{0}^{2} \frac{d Y_{0,1}}{d X} \frac{d Y_{2,2}}{d X} d X=0
\end{aligned}
$$

(18-2)，(52)，(64)，(66)式等を使用して(67-1)， (67-2)式を解くと $V_{\mathrm{A} 2,-1}, V_{\mathrm{A} 2,0}$ は以下となる。

$$
V_{\mathrm{A} 2,-1}=-\frac{\left(k^{2}+3\right)\left(k^{2}-1\right)}{\left(k^{2}-3\right)^{3}} \sin ^{2} \theta, \quad V_{\mathrm{A} 2,0}=0 \text { (68) }
$$

(18-2)，(50)，(51)，(52)，(61)，(68)式を(64)。 (65)，(66)式に代入すると， $Y_{2} ， V_{2} ， T_{2}$ は以下とな る.

$$
\begin{aligned}
& Y_{2}=Y_{2,1} \beta+Y_{2,2} \beta^{2}+\cdots \\
& Y_{2,1}=\frac{3\left(k^{2}-1\right)^{2}}{\left(k^{2}-3\right)^{3}}\left(X-\frac{X^{2}}{2}\right) \sin ^{2} \theta \\
& Y_{2,2}=-\frac{1}{3} \frac{k^{2}+1}{k^{2}-3} X(X-1)(X-2) \sin \theta \cos \theta
\end{aligned}
$$

$$
\begin{aligned}
& V_{2}=V_{2,-1} / \beta+V_{2,0}+\cdots \\
& V_{2,-1}=-\frac{\left(k^{2}+3\right)\left(k^{2}-1\right)}{\left(k^{2}-3\right)^{3}} \sin ^{2} \theta, \quad V_{2,0}=0 \\
& T_{2}=T_{2,-1} / \beta+T_{2,0}+\cdots \\
& T_{2,-1}=-\frac{\left(k^{2}+3\right)\left(k^{2}-1\right)}{\left(k^{2}-3\right)^{3}} \sin ^{2} \theta, T_{2,0}=0
\end{aligned}
$$

(18-2)，(44)，(69)式を(11-4)式に代入すると $S_{2}$ が 得られる。また $\varepsilon_{2} ， \sigma_{2}$ は(27)，(71)，(11-5)式より 得られる。

\section{4. 計 算 結 果}

4.1 圧力による变形挙功 $(16-4)$ ，(27)式に基づ 
き, 中心高さ $h_{\mathrm{u}} / a, h_{0} / a$ と圧力 $P a /\left(E t_{\mathrm{b}}\right)$ の関係を第 2 図に示す， $h_{u} / a=0$ のとき $h_{0} / a$ は，压力が增加す ると急敏に立ち上がった後，縟やかに直線的に増加す る. hu/aが増加すると初期の立ち上がり傾向がなく なる.(27)式及びその両辺を $P$ で微分した関係式等 に基づき，压力 $P a /\left(E t_{h}\right)$ ，初期中心高さ $h_{\mathrm{u}} / a$ ，と中 心高さの压力に対する変化率 $\left(E t_{h} / a^{2}\right) \partial h_{0} / \partial P$ の関係

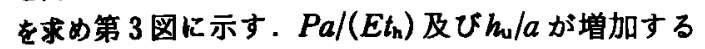
と $\left(E t_{\mathrm{h}} / a^{2}\right) \partial h_{0} / \partial P$ は減少することがわかる. (16-4) 式より $h_{0} / a$ と $\beta$ の関係を求め第 4 図に示す. $h_{0} / a$ が 図に示す篝囲では(16-4)式による $\beta$ はほほ $\beta=2 h_{0} / a$ に等しい. $\beta_{\mathrm{u}}$ と $h_{\mathrm{u}} / a$ の関係も上記と同様である。 (27)，(35)式及び(16-4)式に基づきべース放物線 $\left(h_{B} / a=0.1\right)$ に対する鏡面誤差 $d / a$ に及ほす初期高さ $h_{\mathrm{u}} / a$ 及び圧力 $\mathrm{Pa} / E t_{\mathrm{h}}$ の影筫を第 5 図に示す. 図では 如圧前の膜面はベース放物線の内側にあり，鏡面誤差 は圧力を増加させると減少し，最小值 $(\fallingdotseq 0)$ をとった 後増加することがわかる．鏡面誤差を最小にするとき

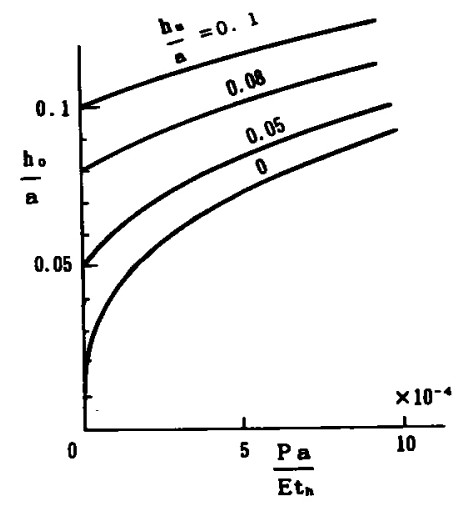

第 2 図王力と中心高さの咸保

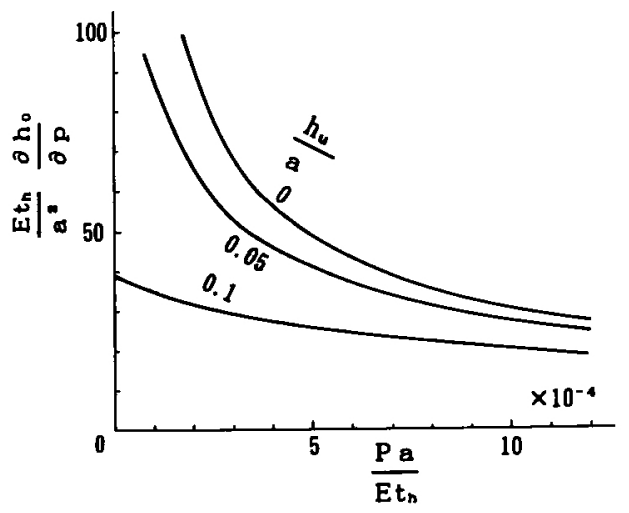

第 3 図 压力 $P a / E t_{h}$, 初期高さ $h_{\mathrm{u}} / a$ と中心高さ変化率 $E t_{\mathrm{h}} / a^{2} \cdot \partial h_{0} / \partial P$ の成保
の圧力は，初期高さが高いほど小さくなっている．

4.2 加圧膜に対する重力の影豐 (52)，(69)式上 り $Y_{1,1}, Y_{1,2}, Y_{2,1}, Y_{2,2}$ 等を以下で表わす(簡単の ため。ここでは $Y_{i j}$ は $Y_{i, j}$ を意味するものとする).

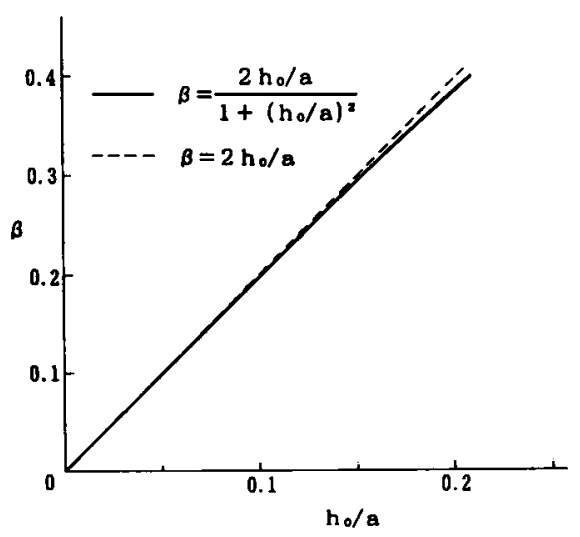

第 4 図 中心点高さ $h_{0} / a$ と $\beta$ の夙倸

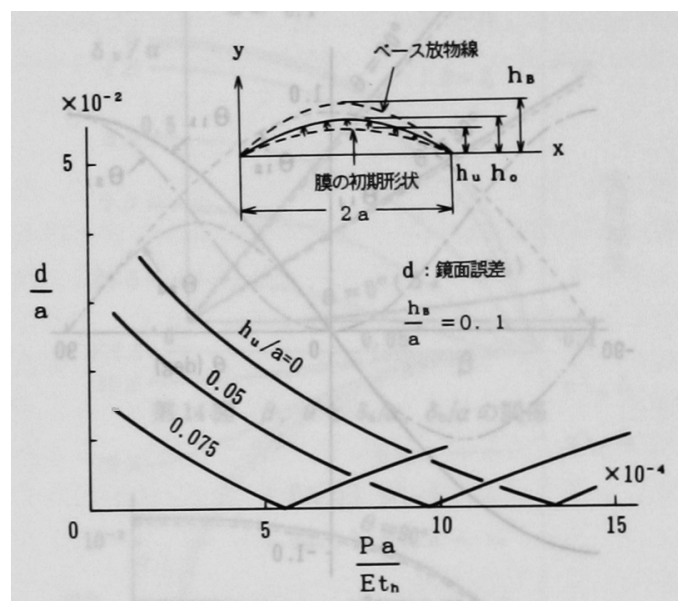

第 5 図 鏡面誤差の圧力による変化

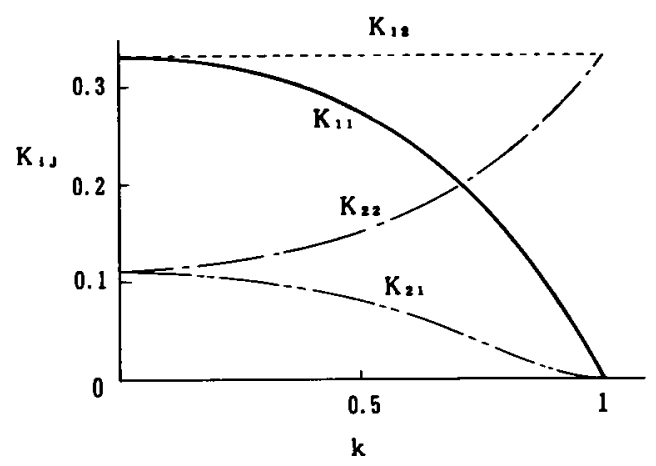

第 6 図 $K_{i v}$ と $k$ の関倸 
$Y_{11}=K_{11} \Theta_{11} \Phi_{11}, \Phi_{11}=X-X^{2} / 2$

$\left.K_{11}=\left(k^{2}-1\right) /\left(k^{2}-3\right), \Theta_{11}=\sin \theta\right\}$

$Y_{12}=K_{12} \Theta_{12} \Phi_{12}, \Phi_{12}=-X(X-1)(X-2)$
$K_{12}=1 / 3, \Theta_{12}=\cos \theta$

$Y_{21}=K_{21} \Theta_{21} \Phi_{21}, \quad \Phi_{21}=-X+X^{2} / 2$

$\left.K_{21}=3\left(k^{2}-1\right)^{2} /\left(-k^{2}+3\right)^{3}, \Theta_{21}=\sin ^{2} \theta\right\}$

$Y_{22}=K_{22} \Theta_{22} \Phi_{22}, \Phi_{22}=X(X-1)(X-2)$

$\left.K_{22}=(1 / 3) \cdot\left(k^{2}+1\right) /\left(3-k^{2}\right), \Theta_{22}=\sin \theta \cos \theta\right\}$

すなわち $Y_{i j}(i, j=1,2)$ は各々 $k, \theta, X$ の関数 $K_{i j}$, $\Theta_{i j} ＼Phi_{i j}$ の積で表わされる． $K_{i j} ， \Theta_{i j}$ をそれぞれ第 6 図及び第 7 図に示す。また $\Phi_{i j}$ を第 8 図に示す。 $\Phi_{11}$ は $X=1$ を中心軸とし $X$ 軸上の点 $X=0,2$ を通る 2 次曲線であり， $\Phi_{12}$ は $X$ 軸上の点 $X=0,1,2$ を通る 3 次曲線である。 $\Phi_{21} ， \Phi_{22}$ はそれぞれ $\Phi_{11} ， \Phi_{12}$ と符 号が逆である。

(72-1)式より $k=0$ (初期形状がフラットな膜面に 対応する)のときの重力方向 $\theta, x / a$ と $y_{11} / a\left(=Y_{11}\right)$ の

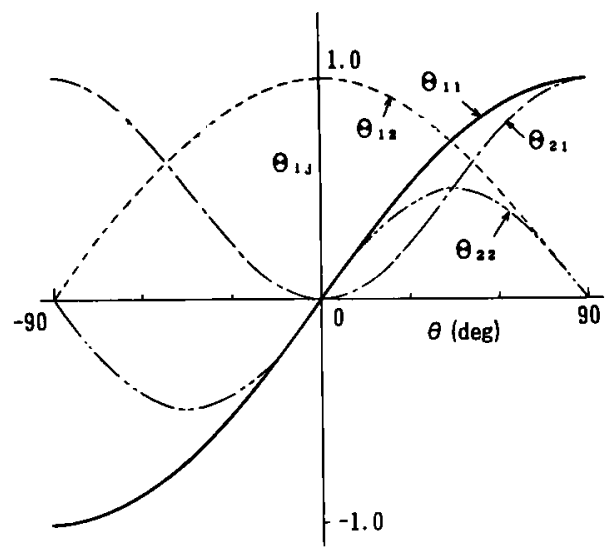

第 7 図 $\theta_{i}$ と $\theta$ の関係

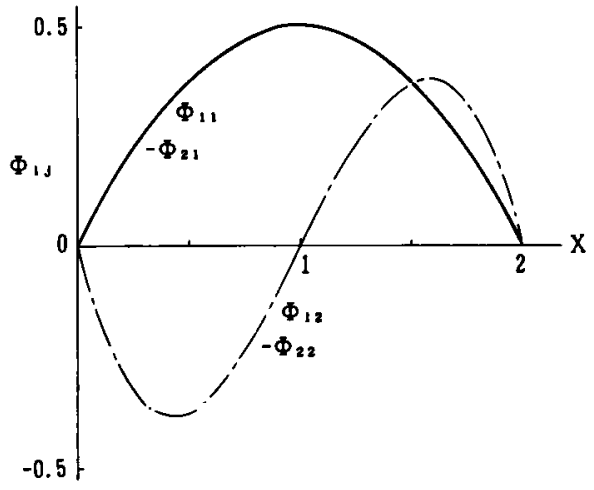

第 8 図
関係を求め第 9 図に示す. $y_{11} / a$ は $x / a=1$ を中心軸と し $x / a$ 軸上の点 $x / a=0,2$ を通る 2 次曲線であり， $\theta$ $=0^{\circ}$ のとき(膜を垂直に立てた場合)， $y_{11} / a=0$, また $\theta= \pm 90^{\circ}$ のと(水平配置の場合)， $y_{11} / a$ の䋓対值は 最大となる（72-1) 式及び第 6 図より， $k$ が増加する と $y_{11} / a$ の絶対值は小さくなることがわかる．(72-2) 式より $\theta, x / a$ と $y_{12} / a\left(=Y_{12}\right)$ の関係を第 10 図に示 す. $y_{12} / a$ は $x / a$ 軸上の点 $x / a=0,1,2$ を通る 3 次曲線 であり，膜を垂直に立てた場合その絶対值は最大とな り，水平配置の場合には 0 になる．また(72-2)式より $y_{12} / a$ は $k$ に依存しないことがわかる.

膜の変形形状 $Y(=y / a)$ は以下で表わされる.

$$
Y=Y_{0}+\Delta Y, \Delta Y=Y_{1} \alpha+Y_{2} \alpha^{2}+\cdots
$$

また $\Delta Y_{\mathrm{a}}, \Delta Y_{\mathrm{b}}$ を以下で定義する。

$$
\Delta Y_{\mathrm{a}}=Y_{1} \alpha, \Delta Y_{\mathrm{b}}=Y_{1} \alpha+Y_{2} \alpha^{2}
$$

(52)，(69)，(74)式を使用して $k=0, \beta=0.1 ， \alpha=$ 0.2 のときの $x / a, \theta$ と $\Delta Y_{\mathrm{a}} / \alpha, \Delta Y_{\mathrm{b}} / \alpha$ の関係(例) $\left(Y_{\mathrm{l}}\right.$, $Y_{2}$ は $\beta$ の 2 次まで考虑)を第 11 図に示す. 第 12 図 は（18-1），(52），(74）式に基づいた垂直配置膜の変形 形状(例) $\left(\Delta Y=\Delta Y_{\mathrm{a}}\right.$ とし $Y_{1}$ は $\beta$ の 2 次まで考虑)を 示す 重力による変形㒭差 $e(\geqq 0)$ を以下で定義す る。

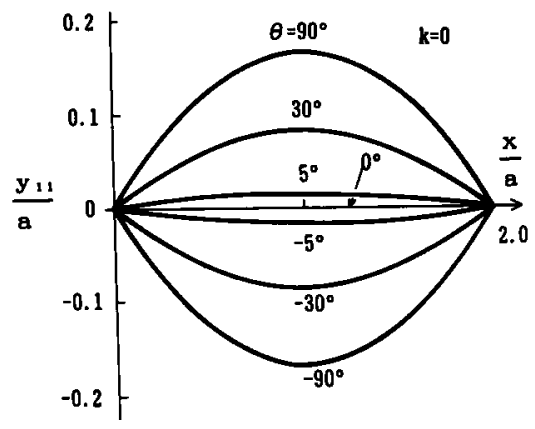

第 9 図 $x / a, \theta$ と $y_{11} / a$ の咸保

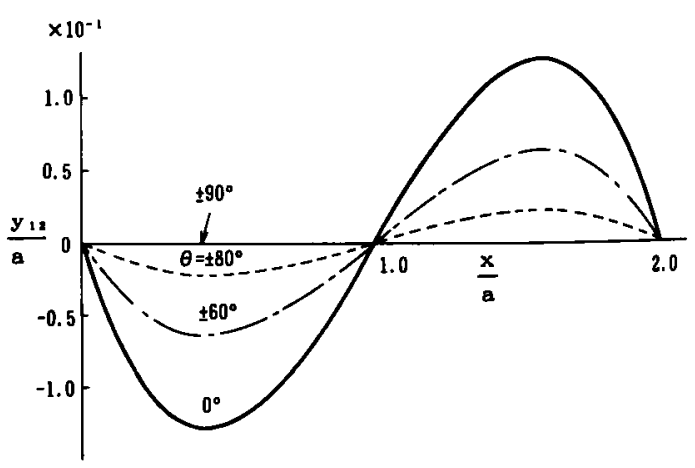

第 10 図 $x / a ， \theta$ と $y_{12} / a$ の関倸 


$$
e^{2}=\frac{1}{2 a} \int_{0}^{2 a}(\Delta y)^{2} d x
$$

ここて $\Delta y=a \Delta Y$ てある. $\delta=e / a$ とすると(75)式は 以下となる.

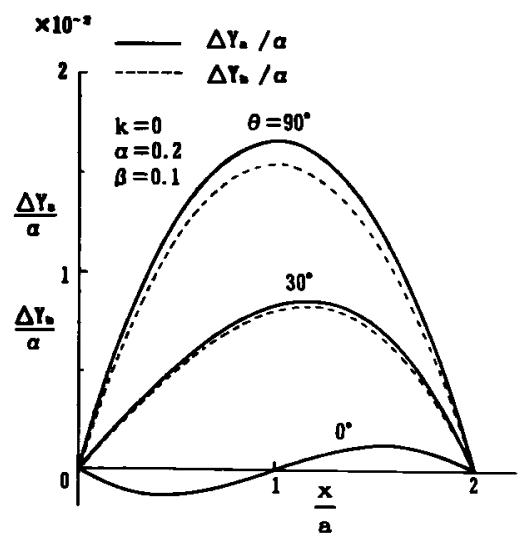

第 11 図 $x / a, \theta$ と $\Delta Y_{\mathrm{a}} / \alpha, \Delta Y_{\mathrm{b}} / \alpha$ の网係

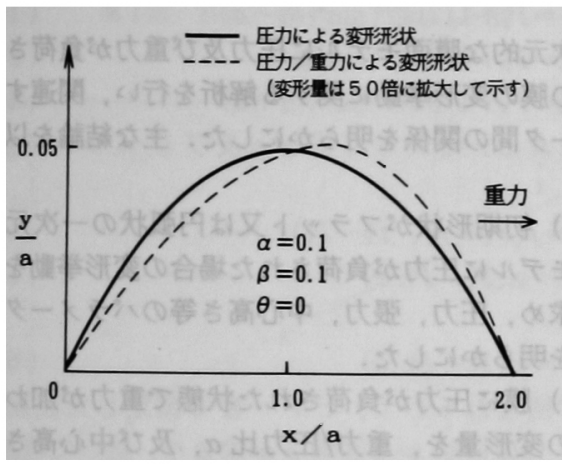

第 12 図莫面の変形形状

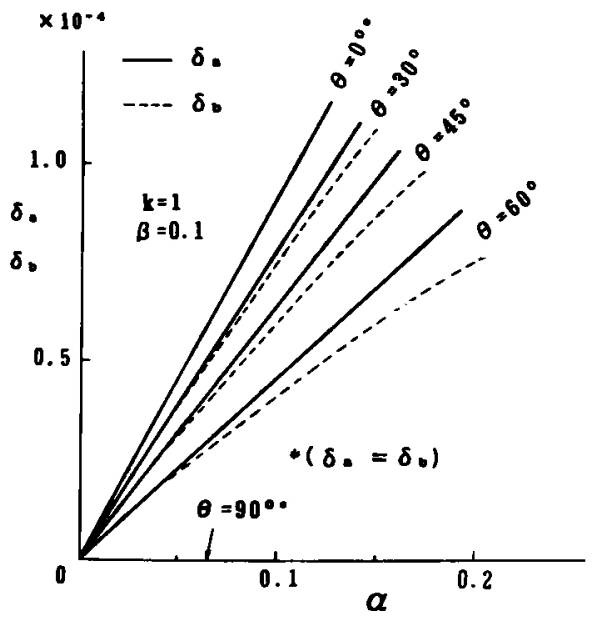

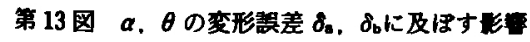

$$
\delta^{2}=\frac{1}{2} \int_{0}^{2}(\Delta Y)^{2} d X
$$

(52)式て $\beta^{2}$ までの項を残して， $\Delta Y=\Delta Y_{\mathrm{a}}$ とした場 合の変形誤差 $\delta_{\mathrm{a}}(\geqq 0)$ は下式で与えられる.

$$
\delta_{\mathrm{a}}^{2}=\left[\frac{2}{15}\left(\frac{k^{2}-1}{k^{2}-3}\right)^{2} \sin ^{2} \theta \beta^{2}+\frac{8}{945} \cos ^{2} \theta \beta^{4}\right] \alpha^{2}
$$

(52)，(69)式で $\beta^{2}$ まで項を牫し， $\Delta Y=\Delta Y_{\mathrm{b}}$ とし た場合の変形誤差 $\delta_{b}(\geqq 0)$ は下式で表わされる.

$$
\begin{aligned}
\delta_{b}^{2}= & {\left[\frac{2}{15}\left(\frac{k^{2}-1}{k^{2}-3}\right)^{2} \sin ^{2} \theta \beta^{2}\left\{1+\frac{3\left(k^{2}-1\right)}{\left(k^{2}-3\right)^{2}} \sin \theta \alpha\right\}^{2}\right.} \\
& \left.+\frac{8}{945} \cos ^{2} \theta \beta^{4}\left\{1+\frac{k^{2}+1}{k^{2}-3} \sin \theta \alpha\right\}^{2}\right] \alpha^{2}(78)
\end{aligned}
$$

(77)式より， $\delta_{\mathrm{a}}$ は明らかに $\alpha, \beta$ の増加関数であり， $k$ の減少関数である。また $(78)$ 式より， $\delta_{\mathrm{b}}$ は $\beta$ の増

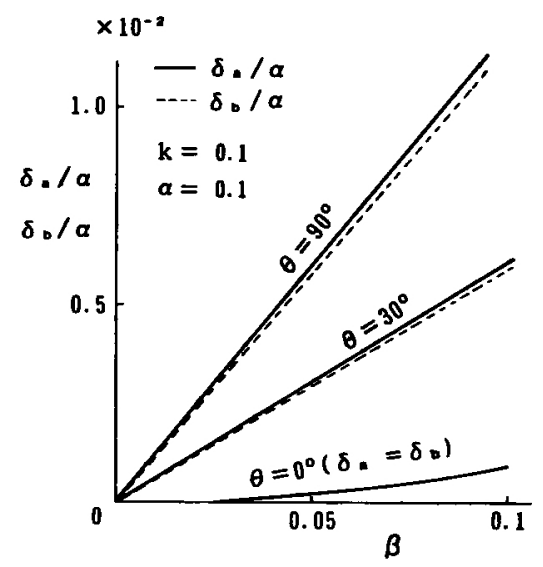

第 14 図 $\beta, \theta$ と $\delta_{\mathrm{a}} / \alpha, \delta_{\mathrm{b}} / \alpha$ の成係

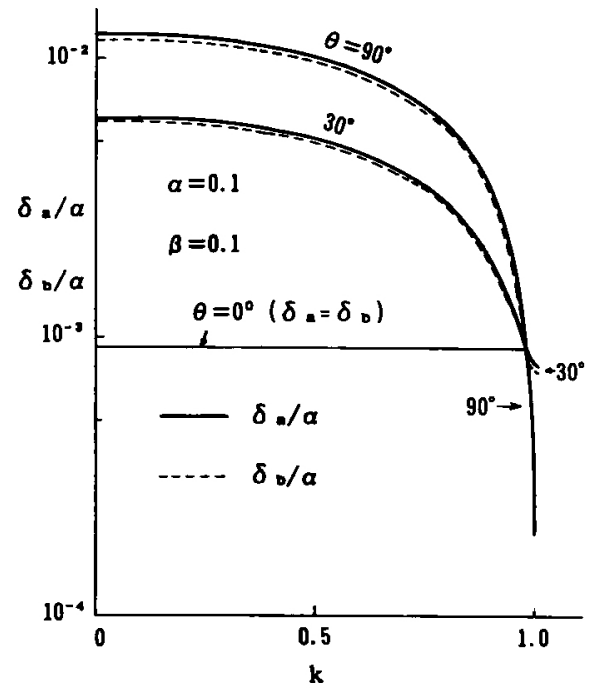

第 15 圀 $k, \theta$ と変形謓差 $\delta_{\mathrm{a}} / \alpha, \delta_{\mathrm{b}} / \alpha$ 
加関数であり，さらに $\alpha$ が小さい值のとき， $\delta_{\mathrm{b}}$ は $\alpha$ の增加関数であることが容易に示される（77)，(78） 式より $\theta=0$ のときは変形誤差は $k$ によらず $\delta_{\mathrm{a}} / \alpha=$ $\delta_{\mathrm{b}} / \alpha$ となる， $\alpha, \theta$ と $\delta_{\mathrm{a}}, \delta_{\mathrm{b}}$ の関係(例)を第 13 図 に， $\beta, \theta$ と $\delta_{\mathrm{a}} / \alpha, \delta_{\mathrm{b}} / \alpha$ の関係(例)を第 14 図に，ま た $k, \theta$ と $\delta_{\mathrm{a}} / \alpha, \delta_{\mathrm{b}} / \alpha$ の関係(例)を第 15 図に示す. 第 13 図，第 14 図において $\alpha, \beta$ を增加させると $\delta_{\mathrm{a}} ， \delta_{\mathrm{b}}$ 増加する．第 15 図において $\theta=90^{\circ} ， 30^{\circ}$ の とき， $k$ が増加すると $\delta_{\mathrm{a}} / \alpha, \delta_{\mathrm{b}} / \alpha$ は減少する， $\theta=0$ のときは $\delta_{\mathrm{a}} / \alpha$ と $\delta_{\mathrm{b}} / \alpha$ は等しく一定值をとる.さらに (77)式より $\delta_{\mathrm{a}} / \alpha$ は $\theta$ の正負によらないことがわか

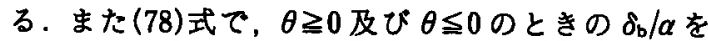
それぞれ， $\delta_{\mathrm{b}}(+|\theta|) / \alpha, \delta_{\mathrm{b}}(-|\theta|) / \alpha$ とすると下式が成 りたつ.

$$
\delta_{\mathrm{b}}(+|\theta|) / \alpha \leqq \delta_{\mathrm{a}} / \alpha \leqq \delta_{\mathrm{b}}(-|\theta|) / \alpha
$$

(77)式を変形すると下式を得る.

$$
\delta_{\mathrm{a}}^{2}=\left[C \sin ^{2} \theta+(8 / 945) \beta^{4}\right] \alpha^{2}
$$

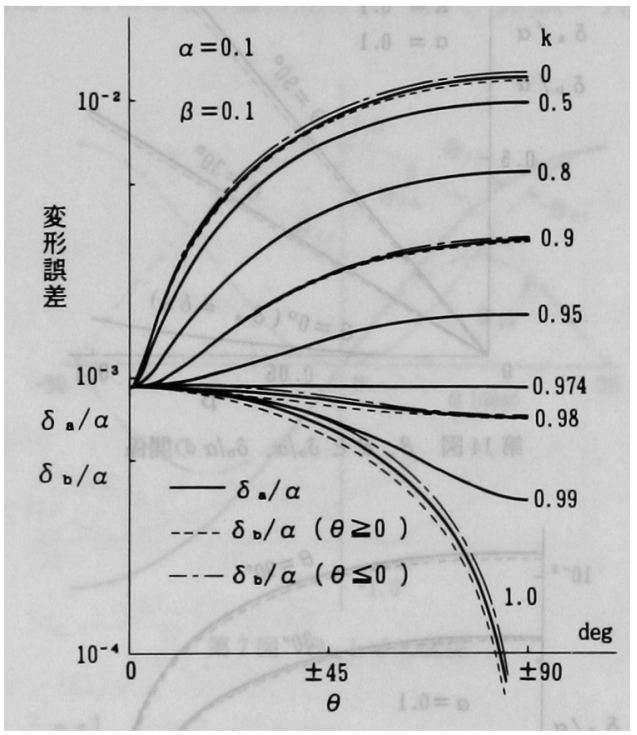

第 16 図重力方向 $\theta, k$ と変形譟差 $\delta_{\mathrm{a}} / \alpha, \delta_{\mathrm{b}} / \alpha$

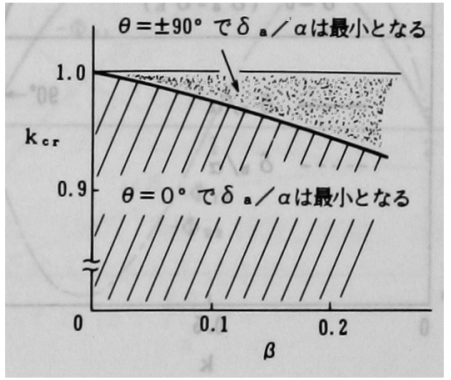

第 17 図 $\beta$ と $k_{\mathrm{cr}}$ の成係

$$
C=\frac{2}{15}\left(\frac{k^{2}-1}{k^{2}-3}\right)^{2} \beta^{2}-\frac{8}{945} \beta^{4}
$$

上式より $-90^{\circ} \leqq \theta \leqq 90^{\circ}$ とすると， $\delta_{\mathrm{a}} / \alpha$ の最小值に 関して以下が成り立つ。

- $C>0$ のとき $\delta_{\mathrm{a}} / \alpha$ は $\theta=0$ で最小值をとる.

- $C<0$ のとき $\delta_{\mathrm{a}} / \alpha$ は $\theta= \pm 90^{\circ}$ で最小值をとる。

- $C=0$ のとき $\delta_{\mathrm{a}} / \alpha$ は $\theta$ によらない.

$\theta, k$ と $\delta_{\mathrm{a}} / \alpha, \delta_{\mathrm{b}} / \alpha$ の関係(例)を第 16 図に示す $(k$ が $0,0.9,0.98,1.0$ のときは $\delta_{\mathrm{a}} / \alpha, \delta_{\mathrm{b}} / \alpha$ を，kが その他の值のときは $\delta_{\mathrm{a}} / \alpha$ を示す). 本図では $k$ がクリ ティカル值 $k_{\mathrm{cr}}\left(k_{\mathrm{cr}}: C=0\right.$ とする $k$ の值であり，この 場合 $k_{\mathrm{cr}} \fallingdotseq 0.974$ となる)以上のとき $C<0$ となり, $\delta_{\mathrm{a}} / \alpha$ は $\theta= \pm 90^{\circ}$ で最小值をとる。また $k$ が $k_{\mathrm{cr}}$ 以下 のときは $(C>0), \delta_{\mathrm{a}} / \alpha$ は $\theta=0^{\circ}$ で最小值をとり，k が $k_{\mathrm{cr}}$ のときは $(C=0) ， \delta_{\mathrm{a}} / \alpha$ は $\theta$ に依存せず一定と なる。.また第 16 図において， $\delta_{\mathrm{a}} / \alpha$ と $\delta_{\mathrm{b}} / \alpha$ は (79)式の 関係を満足していることがわかる. 第 17 図に $\beta$ と $k_{\mathrm{cr}}$ の関係を示す.

\section{5. を と め}

一次元的な膜面モデルに圧力及び重力が負荷された 場合の膜の変形挙動に関する解析を行い, 関連するパ ラメータ間の関係を明らかにした。主な結論を以下に 示す.

（1）初期形状がフラット又は円弧状の一次元的な 膜面モデルに圧力が負荷された場合の変形挙動を解析 的に求め，圧力，張力，中心高さ等のパラメータ間の 関係を明らかにした。

（2）膜に圧力が負荷された状態で重力が加わった 場合の変形量を, 重力/圧力比 $\alpha$, 及び中心高さと両 端距離の比が小さいものとして摄動法により解析し， $\alpha, \beta$ (両端距離と加圧後の円弧の半径の比の $1 / 2$ ), $k$ (加圧前後の $\beta$ の比), 及び $\theta$ (重力の方向)の変形形 状及び変形誤差に及ほす影響を明らかにした.

（3）加圧状態で重力が加わった場合の，重力によ る膜の変形量は $x$ (位置座標)の 2 次式及び 3 次式の組 合せで表わされる．膜が水平に配置されている場合は 2 次式で，また垂直配置の場合は 3 次式で表わされ る.

（4）加圧状態で重力が加わった場合の重力による 変形誤差 $\delta_{\mathrm{a}} ， \delta_{\mathrm{b}}$ を求めた $\left(\delta_{\mathrm{a}}: \alpha\right.$ の 1 次及び $\beta$ の 2 次項 まで考虑， $\delta_{b}: \alpha$ 及び $\beta$ の 2 次項まで考虑). $\delta_{a}, \delta_{b}$ は， $\alpha ， \beta$ の増加関数である. 従って膜に加わる重 力/圧力比が大きい程, また中心高さと両端距離の比 か大きい程、変形誤差は增加する。

(5) 変形誤差 $\delta_{\mathrm{a}} / \alpha$ は， $k$ の減少関数であり, $k$ が 大きいと(加压による変形量が小さいと) $\delta_{\mathbf{a}} / a$ は小さ 
くなる。

(6) $k$ が $k_{\mathrm{cr}}\left(k_{\mathrm{cr}}: \beta\right.$ で定まる值)以上のとき $\delta_{\mathrm{a}} / \alpha$ は, $\theta= \pm 90^{\circ}$ (水平配置膜)で最小となる. $k$ が $k_{\mathrm{cr}}$ 以 下のとき $\delta_{\mathrm{a}} / \alpha$ は $\theta=0^{\circ}$ (垂直配置膜)で最小となる. $k$ が $k_{\mathrm{cr}}$ のときは $\delta_{\mathrm{a}} / \alpha$ は $\theta$ に依存しない.さらに $\delta_{\mathrm{a}} / \alpha$ は $\theta$ の正負によらない.

\section{参考文嗝}

1) Reibaldi,G.G. and Bernasconi, M.C.: Quasat Program: the ESA Reflector, IAF-85-400, 36th Congress of the International Astronautical Federation, Stockholm,
1985.

2) Kato, S., Tekeshita, Y., Sakai, Y., Muragishi, M., Shibayama, Y. and Natori, M.: Concept of Inflatable Elements Supported by Truss Structure for Reflector Application, IAF-88-274, 39th Congress of the International Astronautical Federation, Bangalore, India, 1988 ; also Acta Astronautica, 19, 6/7 (1989), pp. 539-553.

3) Natori, M., Kato, S., Muragishi, O. and Ohnishi, T.: Design and Development of a Modularized Inflatable Reflector, AIAA-90-0998, 31st AIAA/ASME/ASCE/ AHS Structures Structural Dynamics and Material Conference, Long Beach, CA, 1990, pp.2164-2172.

4) Wilson, P E. and Slick, E. M. : Finite Deformation of a Pressurized Membrane Strip, J. Applied Mechanics, June 1965, pp.451-453. 